\title{
The prognostic value of histological subtype in patients with metastatic bladder cancer
}

\author{
Cheng Chen ${ }^{1, *}$, Linkun Hu ${ }^{1, *}$, Ye Chen ${ }^{1}$, Jianquan Hou ${ }^{1}$ \\ ${ }^{1}$ Department of Urology, the First Affiliated Hospital of Soochow University, Suzhou, People's Republic of China \\ *These authors contributed equally to this work
}

Correspondence to: Jianquan Hou, email: houjianquan@suda.edu.cn

Keywords: urinary bladder neoplasms, histology, distant metastasis, prognosis, survival

Received: December 14, $2016 \quad$ Accepted: February 28, $2017 \quad$ Published: March 10, 2017

Copyright: Chen et al. This is an open-access article distributed under the terms of the Creative Commons Attribution License (CC-BY), which permits unrestricted use, distribution, and reproduction in any medium, provided the original author and source are credited.

\section{ABSTRACT}

We aim to evaluate the prognostic effect of the histological sub-type in patients with metastatic bladder cancer based on the Surveillance Epidemiology and End Results database. A total of 2634 eligible patients were included. The histological subtypes were: transitional cell carcinoma (TCC; 75.2\%); adenocarcinoma (3.3\%); squamous cell carcinoma (SQCC; $4.1 \%)$; and small cell carcinoma $(4.3 \%)$. A significant association of adenocarcinoma with better survival outcomes $(P<0.015)$, and that of SQCC with worse outcomes $(P<0.001)$ was observed. On multivariate analysis, adenocarcinoma was significantly associated with longer and SQCC with shorter survival time as compared to TCC. Overall, $1331(50.5 \%)$ patients had a single metastatic site and $523(19.9 \%)$ had multiple sites involved. Single-site metastasis had a better survival outcome than multiple metastases $(P<0.001)$. Histological sub-type and presence of multiple metastatic sites are independent predictors of survival time. Prospective, in-depth research is needed to determine optimal therapeutic strategies for different histological subtypes of bladder cancer with different metastatic patterns.

\section{INTRODUCTION}

Bladder cancer $(\mathrm{BC})$ has the fifth highest incidence among all cancers in the United States; an estimated 76960 new cases of $\mathrm{BC}$ and 16390 deaths from $\mathrm{BC}$ occurred in 2016 [1]. It is also the 9th most common cancer and the 13th most common cause of death worldwide [2]. Urothelial carcinoma (transitional cell carcinoma, TCC) is the most common histological sub-type of primary BC, which accounts for $>90 \%$ of all bladder tumors. Other histological subtypes include squamous cell carcinoma (SQCC), adenocarcinoma (AD), small cell carcinoma (SCC) and some other rare non-epithelial subtypes. Among these, SQCC, AD and SCC account for less than $5 \%, 2 \%[3]$ and $1 \%[4,5]$ of all primary bladder tumors, respectively.

The rare occurrence of non-TCC subtypes precludes large, prospective studies to compare outcomes. Retrospective and cohort analyses remain the primary tools for clinical research. Previous studies of the impact of non-TCC histology on survival have yielded inconsistent results [6-9]. Some have reported no difference in survival between SQCC and TCC [7-9]. However, a multiinstitutional retrospective study to assess the impact of non-TCC histology on bladder cancer-specific outcomes in patients treated with radical cystectomy [6] suggested that non-TCC histology portends worse clinical outcomes. This may reflect a greater propensity for locally aggressive disease and distant metastasis, as well as differential response to chemotherapy or radiotherapy.

Approximately $25 \%$ of all TCC patients will have muscle-invasive and metastatic disease. The prevalence of bone metastasis was reported to be $30-40 \%$ in patients with metastatic TCC [10] and the presence of distant (lung, liver, bone) metastases were reported to correlate with shortened survival [11-17]. However, the effect of other histological subtypes on clinical outcomes in patients with metastatic $\mathrm{BC}$ remains unclear. Thus, we evaluated TCC and three other rare BC histological subtypes in a contemporary, population-based cohort with an emphasis on the metastatic frequency of BC histology and their effect on overall- and cancer-specific survival. 


\section{RESULTS}

Data pertaining to 2634 patients who had stage M1 BC, and information on specific metastatic site in the period between January 2010 and December 2013, were extracted. The baseline demographic and clinical characteristics are summarized in Table 1. Of all patients with metastatic BC, the histological subtypes included TCC $(n=1981[75.2 \%]), \mathrm{AD}(n=88[3.3 \%]), \mathrm{SQCC}$ $(n=107[4.1 \%])$ and SCC $(n=114[4.3 \%])$. A total of $1331(50.5 \%)$ patients had a single metastatic site (bone, brain, liver or lung), while $523(19.9 \%)$ had metastatic lesions at more than one site. In single metastatic BC patients, $575(43.2 \%)$ of them had bone metastasis, $24(1.8 \%)$ with brain metastasis, $280(21 \%)$ with liver metastasis and $452(34 \%)$ with lung metastasis.

Median duration of follow-up was 5 months (range, 0 to 47$)$. A total of 2134 (81\%) patients died in the group. Kaplan-Meier curves and median OS and CSS were calculated. The median OS and CSS for TCC were 5 and 10 months (range, 0 to 47), respectively; 6 and 25 months (range, 0-47) for $\mathrm{AD}, 3$ and 5 months (range, 0-27) for SQCC and 7 and 11 months (range, $0-43$ ) for SCC, respectively. As shown in Figure 1, the median OS and CSS for AD was significantly higher than that for other histological types $(P<0.015)$. The median OS and CSS for SQCC were significantly lower than that for the other histological types $(P<0.001)$. However, no significant difference in median OS and CSS was observed between TCC and SCC ( $P=0.877$ and 0.686 , respectively).

The median OS and CSS in patients with a single metastatic site was 5 and 9 months (range, $0-47$ ), respectively, while that in patients with more than one metastatic site was 3 and 6 months (range, $0-43$ ), respectively. As shown in Figure 2, the median OS and CSS of patients with multiple metastatic sites was significantly lower than that of patients with a single metastatic site $(P<0.001)$. Among patients with a single metastatic lesion, the frequency of bone and brain metastasis was almost the same. Lung was the most common site of metastasis in patients with SQCC $(54.5 \%)$, while it was the least common metastatic site $(3.7 \%)$ in those with SCC. Liver was the most frequent metastatic site in patients with SCC (53.7\%). No brain metastasis was found in patients with AD and SQCC. As shown in Figure 3, a significant difference with respect to liver and lung metastasis was observed between SCC and other histological types $(P \leq 0.004)$, while a significant difference in lung metastasis was observed between SQCC with TCC and SCC $(P<0.006)$.

On univariate analysis (Table 2), thirteen variables showed a significant association with OS; these included age ( $>65$ years old), being widowed, pathological $\mathrm{T}$ $(\mathrm{T} 1, \mathrm{~T} 2, \mathrm{~T} 3, \mathrm{~T} 4)$ and $\mathrm{N}(\mathrm{N} 1, \mathrm{~N} 2, \mathrm{~N} 3)$ stages, history of surgery, presence of multiple metastatic sites, and $\mathrm{AD}$ and SQCC histological subtypes. Five variables showed a significant association with CSS (married status, history of surgery, presence of multiple metastatic sites, $\mathrm{AD}$ and SQCC histological subtypes). Four variables showed a significant association with both OS and CSS (history of surgery, presence of multiple metastatic sites, $A D$ and SQCC histological subtypes). About $67.7 \%$ of all patients had undergone a surgical procedure, which included transurethral resection and partial, simple or radical cystectomy. As 2440 patients $(92.6 \%)$ with metastatic sites were diagnosed at autopsy, only $78(3 \%)$ patients

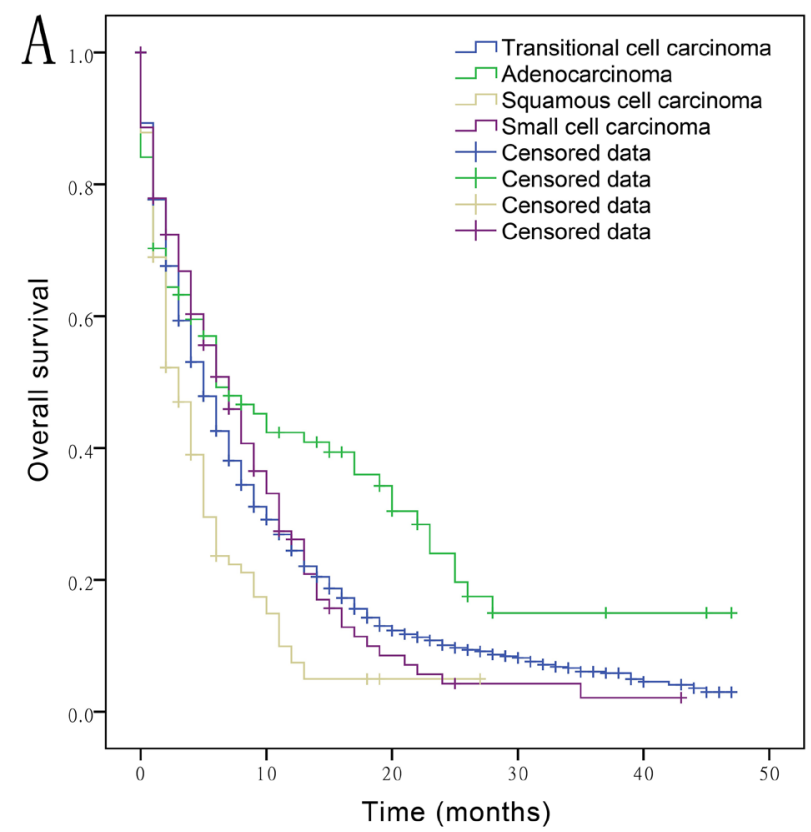

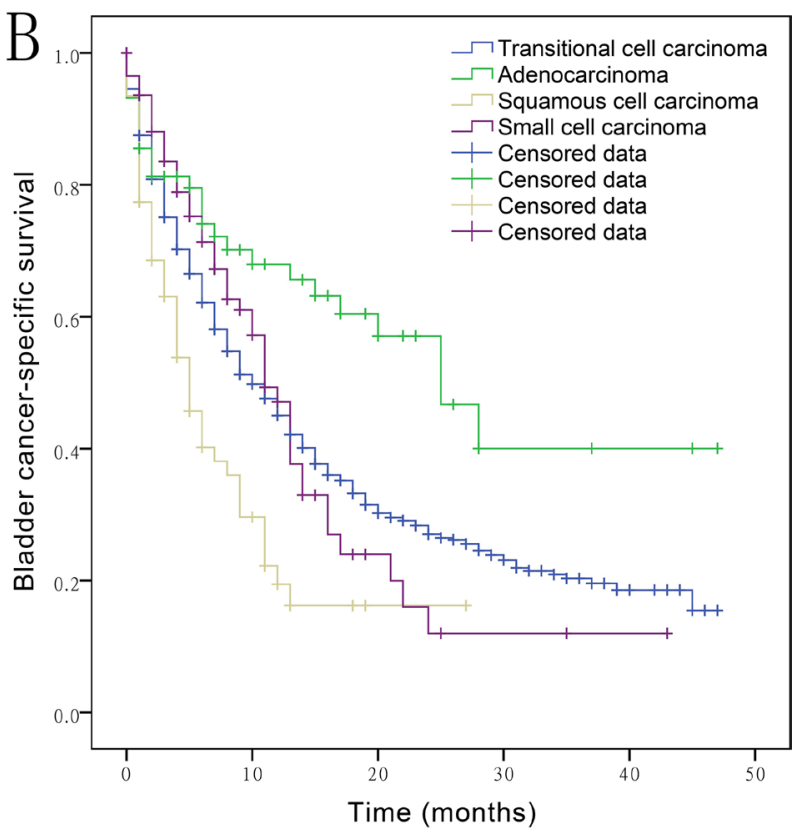

Figure 1: Overall survival (A) and bladder cancer-specific survival (B) in bladder cancer patients with transitional cell carcinoma, adenocarcinoma, squamous cell carcinoma, small cell carcinoma with distant metastasis. 
Table 1: Clinical features associated with various histological subtypes of bladder cancer patients

\begin{tabular}{|c|c|c|c|c|c|c|}
\hline Variables & $\begin{array}{l}\text { Overall } \\
\text { Patients }\end{array}$ & $\begin{array}{c}\text { Transitional } \\
\text { cell carcinoma }\end{array}$ & Adenocarcinoma & $\begin{array}{l}\text { Squamous cell } \\
\text { carcinoma }\end{array}$ & $\begin{array}{l}\text { Small cell } \\
\text { carcinoma }\end{array}$ & $P$ value \\
\hline No. of Patients & 2634 & & & & & \\
\hline Age $(n(\%))$ & & & & & & $<0.001$ \\
\hline$\leq 65$ & $836(31.7 \%)$ & $615(31 \%)$ & $47(53.4 \%)$ & $40(37.4 \%)$ & $31(27.2 \%)$ & \\
\hline$>65$ & $1798(68.3 \%)$ & $1366(69 \%)$ & $41(46.6 \%)$ & $67(62.6 \%)$ & $83(72.8 \%)$ & \\
\hline Gender $(n(\%))$ & & & & & & $<0.001$ \\
\hline male & $1853(70.3 \%)$ & $1418(71.6 \%)$ & $58(65.9 \%)$ & $52(48.6 \%)$ & $94(82.5 \%)$ & \\
\hline female & $781(29.7 \%)$ & $563(28.4 \%)$ & $30(34.1 \%)$ & $55(51.4 \%)$ & $20(17.5 \%)$ & \\
\hline Race $(n(\%))$ & & & & & & 0.003 \\
\hline White & $2227(84.5 \%)$ & $1692(85.5 \%)$ & $65(73.9 \%)$ & $85(79.4 \%)$ & $105(92.1 \%)$ & \\
\hline Black & $262(9.9 \%)$ & $185(9.4 \%)$ & $18(20.5 \%)$ & $15(14 \%)$ & $7(6.1 \%)$ & \\
\hline Other & $142(5.4 \%)$ & $101(5.1 \%)$ & $5(5.7 \%)$ & $7(6.5 \%)$ & $2(1.8 \%)$ & \\
\hline Unknown & $3(0.1 \%)$ & & & & & \\
\hline $\begin{array}{l}\text { Marital status } \\
(n(\%))\end{array}$ & & & & & & 0.001 \\
\hline Single & $426(16.2 \%)$ & $307(16.2 \%)$ & $27(30.7 \%)$ & $22(21.8 \%)$ & $8(7.2 \%)$ & \\
\hline Married & $1262(47.9 \%)$ & $963(51 \%)$ & $42(47.7 \%)$ & $50(49.5 \%)$ & $71(64 \%)$ & \\
\hline $\begin{array}{l}\text { Divorced/ } \\
\text { Separated }\end{array}$ & $338(12.8 \%)$ & $260(13.8 \%)$ & $7(8 \%)$ & $9(8.9 \%)$ & $15(13.5 \%)$ & \\
\hline Widowed & $491(18.6 \%)$ & $360(19 \%)$ & $12(13.6 \%)$ & $20(19.8 \%)$ & $17(15.3 \%)$ & \\
\hline Unknown & $117(4.4 \%)$ & & & & & \\
\hline T stage $(n(\%))$ & & & & & & $<0.001$ \\
\hline $\mathrm{T} 0+\mathrm{Tx}$ & $585(22.2 \%)$ & $322(16.3 \%)$ & $28(31.8 \%)$ & $21(19.6 \%)$ & $22(19.3 \%)$ & \\
\hline $\mathrm{T} 1$ & $385(14.6 \%)$ & $316(16 \%)$ & $10(11.4 \%)$ & $11(10.3 \%)$ & $17(14.9 \%)$ & \\
\hline $\mathrm{T} 2$ & $948(36 \%)$ & $813(41 \%)$ & $17(19.3 \%)$ & $25(23.4 \%)$ & $44(38.6 \%)$ & \\
\hline T3 & $227(8.6 \%)$ & $177(8.9 \%)$ & $13(14.8 \%)$ & $7(6.5 \%)$ & $10(8.8 \%)$ & \\
\hline $\mathrm{T} 4$ & $489(18.6 \%)$ & $353(17.8 \%)$ & $20(22.7 \%)$ & $43(40.2 \%)$ & $21(18.4 \%)$ & \\
\hline N stage $(n(\%))$ & & & & & & 0.008 \\
\hline $\mathrm{N} 0+\mathrm{Nx}$ & $1815(68.9 \%)$ & $1335(67.4 \%)$ & $71(80.7 \%)$ & $64(59.8 \%)$ & $70(61.4 \%)$ & \\
\hline N1 & $245(9.3 \%)$ & $189(9.5 \%)$ & $6(6.8 \%)$ & $18(16.8 \%)$ & $11(9.6 \%)$ & \\
\hline $\mathrm{N} 2$ & $439(16.7 \%)$ & $344(17.4 \%)$ & $11(12.5 \%)$ & $17(15.9 \%)$ & $29(25.4 \%)$ & \\
\hline N3 & $135(5.1 \%)$ & $113(5.7 \%)$ & $0(0 \%)$ & $8(7.5 \%)$ & $4(3.5 \%)$ & \\
\hline Grade $(n(\%))$ & & & & & & $<0.001$ \\
\hline G1 & $21(0.8 \%)$ & $12(0.8 \%)$ & $1(2 \%)$ & $7(9.2 \%)$ & $0(0 \%)$ & \\
\hline G2 & $80(3 \%)$ & $49(3.1 \%)$ & $9(18.4 \%)$ & $20(26.3 \%)$ & $0(0 \%)$ & \\
\hline G3 & $657(24.9 \%)$ & $481(30.3 \%)$ & $36(73.5 \%)$ & $37(48.7 \%)$ & $31(50.8 \%)$ & \\
\hline G4 & $1126(42.7 \%)$ & $1045(65.8 \%)$ & $3(6.1 \%)$ & $12(15.8 \%)$ & $30(49.2 \%)$ & \\
\hline Unknown & $750(28.5 \%)$ & & & & & \\
\hline Surgery $(n(\%))$ & & & & & & $<0.001$ \\
\hline No & $845(32.1 \%)$ & $484(24.5 \%)$ & $41(46.6 \%)$ & $42(39.3 \%)$ & $27(23.7 \%)$ & \\
\hline Yes & $1784(67.7 \%)$ & $1494(75.5 \%)$ & $47(53.4 \%)$ & $65(60.7 \%)$ & $87(76.3 \%)$ & \\
\hline Unknown & $5(0.2 \%)$ & $3(0.2 \%)$ & $0(0 \%)$ & $0(0 \%)$ & $0(0 \%)$ & \\
\hline $\begin{array}{l}\text { Radiotherapy } \\
(n(\%))\end{array}$ & & & & & & 0.414 \\
\hline
\end{tabular}




\begin{tabular}{|c|c|c|c|c|c|c|}
\hline No & $2055(78 \%)$ & $1521(77.5 \%)$ & $72(81.8 \%)$ & $87(82.9 \%)$ & $86(75.4 \%)$ & \\
\hline Yes & $553(21 \%)$ & $442(22.5 \%)$ & $16(18.2 \%)$ & $18(17.1 \%)$ & $28(24.6 \%)$ & \\
\hline Unknown & $26(1 \%)$ & & & & & \\
\hline $\begin{array}{l}\text { Distant metastasis } \\
(n(\%))\end{array}$ & & & & & & 0.031 \\
\hline $\begin{array}{l}\text { Single site } \\
(n(\%))\end{array}$ & $1331(50.5 \%)$ & $1014(51.2 \%)$ & $41(46.6 \%)$ & $44(41.1 \%)$ & $54(47.4 \%)$ & \\
\hline Only bone & $575(43.2 \%)$ & $468(46.2 \%)$ & $17(43.6 \%)$ & $15(34.1 \%)$ & $22(40.7 \%)$ & 0.358 \\
\hline Only brain & $24(1.8 \%)$ & $20(2 \%)$ & $0(0 \%)$ & $0(0 \%)$ & $1(1.9 \%)$ & 0.635 \\
\hline Only liver & $280(21 \%)$ & $179(17.7 \%)$ & $10(24.4 \%)$ & $5(11.4 \%)$ & $29(53.7 \%)$ & $<0.001$ \\
\hline Only lung & $452(34 \%)$ & $347(34.2 \%)$ & $14(34.1 \%)$ & $24(54.5 \%)$ & $2(3.7 \%)$ & $<0.001$ \\
\hline Multiple sites & $523(19.9 \%)$ & $377(27.1 \%)$ & $15(26.8 \%)$ & $15(25.4 \%)$ & $38(41.3 \%)$ & \\
\hline Unknown & $780(29.6 \%)$ & & & & & \\
\hline \multicolumn{7}{|l|}{ Histology $(n(\%))$} \\
\hline $\begin{array}{l}\text { Transitional cell } \\
\text { carcinoma }\end{array}$ & $1981(75.2 \%)$ & & & & & \\
\hline Adenocarcinoma & $88(3.3 \%)$ & & & & & \\
\hline $\begin{array}{l}\text { Squamous cell } \\
\text { carcinoma }\end{array}$ & $107(4.1 \%)$ & & & & & \\
\hline $\begin{array}{l}\text { Small cell } \\
\text { carcinoma }\end{array}$ & $114(4.3 \%)$ & & & & & \\
\hline Other & $462(17.5 \%)$ & & & & & \\
\hline
\end{tabular}

had undergone surgery at the site of distant metastases. Significantly decreased hazard for OS and CSS was observed in patients who underwent surgery as compared to that in patients who did not undergo surgery (Hazard ratio [HR]: $0.660,0.829$, respectively). Presence of multiple metastatic sites was associated with lower OS and CSS (HR: 1.423, 1.537, respectively) than that associated with single site metastasis. Specifically, AD was associated

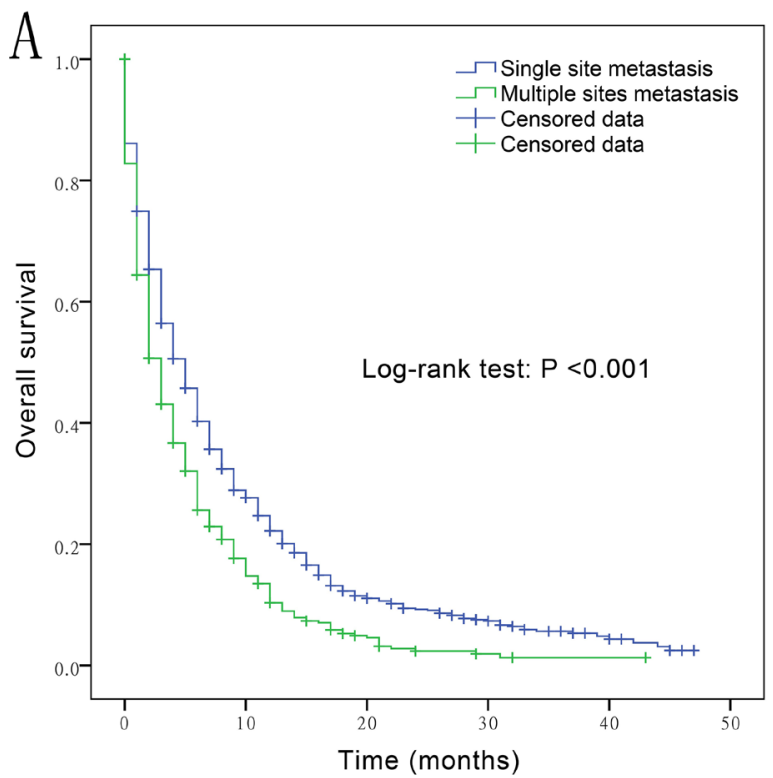

with longer OS and CSS (HR: 0.697, 0.567, respectively) than that associated with the referent TCC. In contrast, SQCC was associated with shorter OS and CSS (HR: $1.504,1.739$, respectively) as compared to TCC.

Variables significantly associated with survival in univariate analysis were included in the multivariate analysis (Table 3). The effect of presence of multiple metastatic sites was further increased after accounting

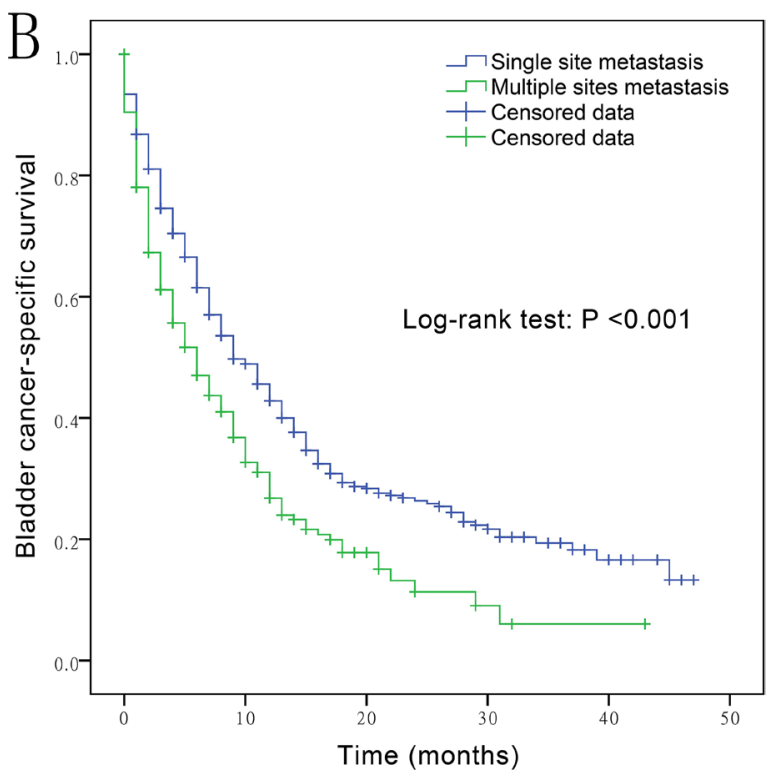

Figure 2: Overall survival (A) and bladder cancer-specific survival (B) in bladder cancer patients with single metastatic site $v s$. multiple metastatic sites. 
Table 2: Univariate analysis of overall survival and bladder cancer-specific survival in patients with metastatic bladder cancer

\begin{tabular}{|c|c|c|c|c|c|c|}
\hline \multirow{2}{*}{ Variables } & \multicolumn{3}{|c|}{ Overall survival } & \multicolumn{3}{|c|}{ Bladder cancer-specific survival } \\
\hline & Hazard Ratio & $95 \% \mathrm{CI}$ & $P$ value & Hazard Ratio & $95 \% \mathrm{CI}$ & $P$ value \\
\hline \multicolumn{7}{|l|}{ Age } \\
\hline$\leq 65$ & 1.000 (reference) & & & 1.000 (reference) & & \\
\hline$>65$ & 1.339 & 1.220 to 1.469 & $<0.001$ & 1.038 & 0.922 to 1.168 & 0.540 \\
\hline \multicolumn{7}{|l|}{ Gender } \\
\hline male & 1.000 (reference) & & & 1.000 (reference) & & \\
\hline female & 0.917 & 0.836 to 1.006 & 0.066 & 0.909 & 0.804 to 1.027 & 0.127 \\
\hline \multicolumn{7}{|l|}{ Race } \\
\hline White & 1.000 (reference) & & & 1.000 (reference) & & \\
\hline Black & 1.076 & 0.935 to 1.240 & 0.307 & 0.995 & 0.820 to 1.207 & 0.960 \\
\hline Other & 0.936 & 0.767 to 1.142 & 0.514 & 0.864 & 0.657 to 1.135 & 0.294 \\
\hline \multicolumn{7}{|l|}{ Marital status } \\
\hline Single & 1.000 (reference) & & & 1.000 (reference) & & \\
\hline Married & 0.885 & 0.783 to 1.001 & 0.052 & 0.796 & 0.680 to 0.933 & 0.005 \\
\hline $\begin{array}{l}\text { Divorced/ } \\
\text { Separated }\end{array}$ & 0.990 & 0.845 to 1.160 & 0.905 & 0.931 & 0.759 to 1.142 & 0.491 \\
\hline Widowed & 1.166 & 1.010 to 1.345 & 0.036 & 0.967 & 0.799 to 1.169 & 0.727 \\
\hline \multicolumn{7}{|l|}{ T stage } \\
\hline $\mathrm{T} 0+\mathrm{Tx}$ & 1.000 (reference) & & & 1.000 (reference) & & \\
\hline $\mathrm{T} 1$ & 0.758 & 0.657 to 0.875 & $<0.001$ & 0.960 & 0.787 to 1.172 & 0.690 \\
\hline $\mathrm{T} 2$ & 0.722 & 0.644 to 0.810 & $<0.001$ & 0.985 & 0.839 to 1.157 & 0.855 \\
\hline T3 & 0.667 & 0.562 to 0.790 & $<0.001$ & 0.938 & 0.750 to 1.174 & 0.578 \\
\hline $\mathrm{T} 4$ & 0.847 & 0.743 to 0.967 & 0.014 & 1.043 & 0.866 to 1.256 & 0.656 \\
\hline \multicolumn{7}{|l|}{ N stage } \\
\hline $\mathrm{N} 0+\mathrm{Nx}$ & 1.000 (reference) & & & 1.000 (reference) & & \\
\hline N1 & 0.801 & 0.685 to 0.937 & 0.005 & 0.913 & 0.747 to 1.115 & 0.371 \\
\hline N2 & 0.853 & 0.759 to 0.959 & 0.008 & 0.958 & 0.824 to 1.114 & 0.579 \\
\hline N3 & 0.753 & 0.617 to 0.919 & 0.005 & 0.869 & 0.675 to 1.119 & 0.277 \\
\hline \multicolumn{7}{|l|}{ Grade } \\
\hline G1 & 1.000 (reference) & & & 1.000 (reference) & & \\
\hline $\mathrm{G} 2$ & 1.019 & 0.595 to 1.745 & 0.945 & 0.944 & 0.443 to 2.011 & 0.880 \\
\hline G3 & 1.246 & 0.769 to 2.019 & 0.372 & 1.033 & 0.515 to 2.072 & 0.928 \\
\hline G4 & 1.088 & 0.673 to 1.758 & 0.731 & 0.875 & 0.435 to 1.758 & 0.708 \\
\hline \multicolumn{7}{|l|}{ Surgery } \\
\hline No & 1.000 (reference) & & & 1.000 (reference) & & \\
\hline Yes & 0.660 & 0.603 to 0.722 & $<0.001$ & 0.829 & 0.732 to 0.939 & 0.003 \\
\hline \multicolumn{7}{|l|}{ Radiotherapy } \\
\hline No & 1.000 (reference) & & & 1.000 (reference) & & \\
\hline Yes & 0.918 & 0.827 to 1.018 & 0.105 & 0.919 & 0.801 to 1.055 & 0.233 \\
\hline \multicolumn{7}{|l|}{ Distant metastasis } \\
\hline Single site & 1.000 (reference) & & & 1.000 (reference) & & \\
\hline Multiple sites & 1.423 & 1.275 to 1.588 & $<0.001$ & 1.537 & 1.331 to 1.774 & $<0.001$ \\
\hline
\end{tabular}




\begin{tabular}{|l|c|c|c|l|l|c|}
\hline Histology & & & & & & \\
\hline $\begin{array}{l}\text { Transitional cell } \\
\text { carcinoma }\end{array}$ & 1.000 (reference) & & & 1.000 (reference) & & \\
\hline Adenocarcinoma & 0.697 & 0.540 to 0.889 & $\mathbf{0 . 0 0 5}$ & 0.567 & 0.391 to 0.821 & $\mathbf{0 . 0 0 3}$ \\
\hline $\begin{array}{l}\text { Squamous cell } \\
\text { carcinoma }\end{array}$ & 1.504 & 1.216 to 1.862 & $<\mathbf{0 . 0 0 1}$ & 1.739 & 1.335 to 2.265 & $<\mathbf{0 . 0 0 1}$ \\
\hline $\begin{array}{l}\text { Small cell } \\
\text { carcinoma }\end{array}$ & 0.985 & 0.800 to 1.213 & 0.888 & 0.946 & 0.715 to 1.251 & 0.696 \\
\hline
\end{tabular}

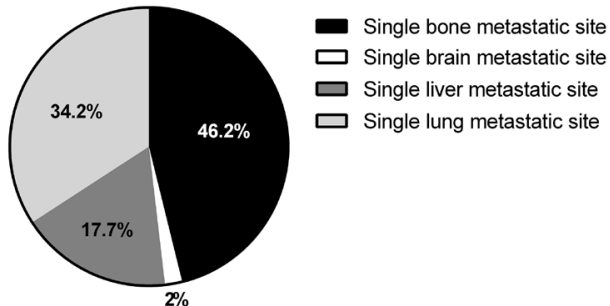

Transitional cell carcinoma

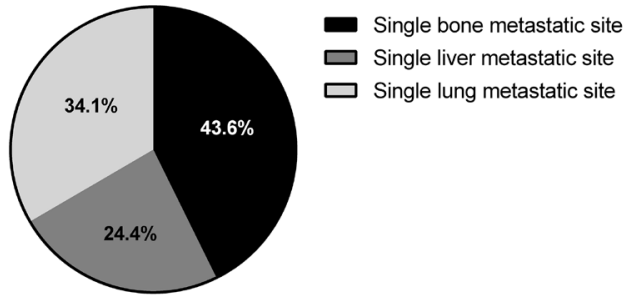

Adenocarcinoma

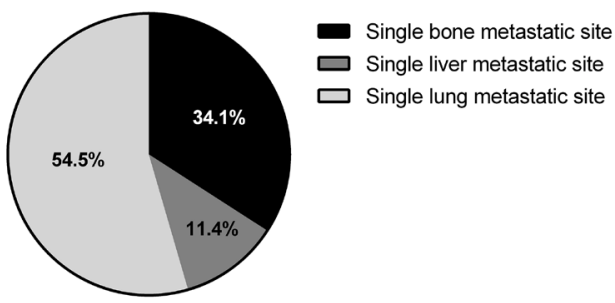

Squamous cell carcinoma

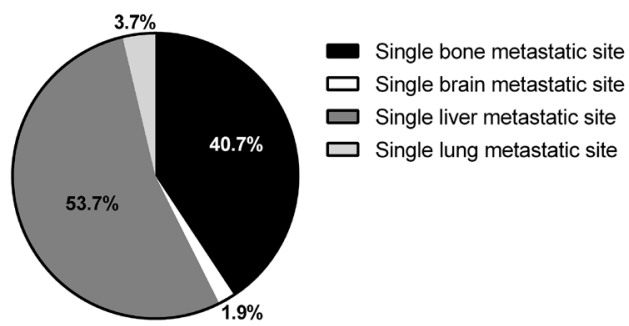

Small cell carcinoma

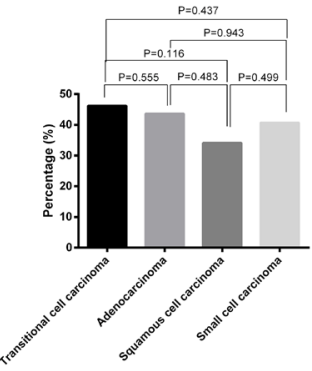

Single bone metastatic site

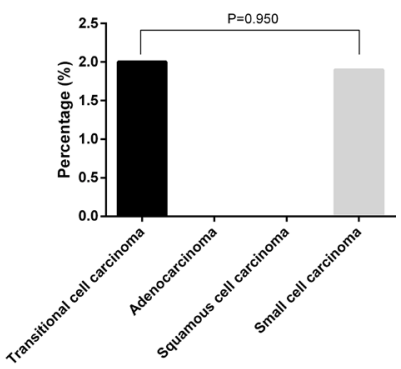

Single brain metastatic site

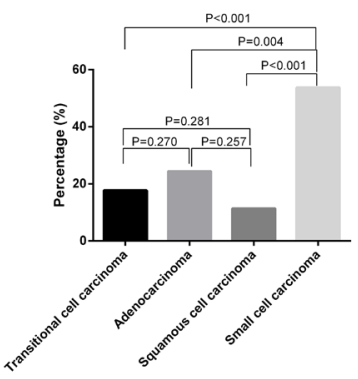

Single liver metastatic site

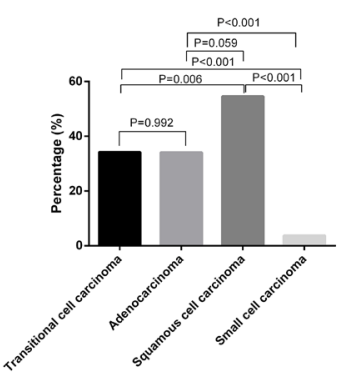

Single lung metastatic site

Figure 3: Metastatic frequency in patients with single-site metastatic bladder cancer by histological subtype. 
for other covariates (HRs for OS and CSS: 1.428 and 1.605, respectively, versus presence of single metastatic site). Compared with TCC, a lower hazard for OS and CSS was identified in patients with AD (HR: 0.593, 0.599 , respectively), while a higher hazard of mortality was found in those with SQCC (HR: 1.496, 1.733 respectively). Other variables significantly associated with OS on multivariate analysis included age ( $>65$ years old) and history of surgery. Age $>65$ years was associated with shorter OS (HR: 1.273 vs. age $<65$ years). Patients who had a history of surgery tended to have longer OS (HR: $0.729 v s$. those with no history of surgery).

\section{DISCUSSION}

We conducted a retrospective cohort study using data from the SEER database to investigate the effect of histological sub-type on survival in patients with metastatic BC. Our study revealed several important findings. First, although the association between histological subtype and prognosis of $\mathrm{BC}$ has been investigated before, previous population-based studies were limited only to one rare histological subtype of BC such as SQCC [7-9], AD $[18,19]$ or SCC $[4,5,20-24]$, or had relatively small sample sizes [6]. SQCC histology was reported to be an independent predictor of higher all-cause and bladder cancer-specific mortality as compared to TCC among patients with advanced stages (AJCC stage III/IV) [7]. However, some studies found no difference in CSS associated with SQCC and TCC [6, 8, 9, 25]. A large cohort study showed that patients with primary AD were not associated with worse prognosis than patients with TCC [26]. We found that AD patients had better survival outcomes than those with conventional TCC, while SQCC had worse outcomes than TCC. Further, there were no significant differences in OS and CSS between TCC and SCC patients in stage M1 group, which is in accordance with results of a previous study [27].

Secondly; we discovered a difference in metastatic tendency between the SQCC and SCC subtypes of BC. We found that SQCC metastasizes predominantly to lung $(54.5 \%)$, while SCC metastasizes predominantly to liver $(53.7 \%)$ and is least likely to metastasize to lung $(3.7 \%)$ when compared with other histological subtypes of BC. These results are in line with studies conducted at the M. D. Anderson Cancer Center [28] and Mayo Clinic [29]. Although brain metastases are a frequent complication in patients with SCC of the lung, they do not appear to be a common metastatic site in patients with SCC of the bladder $[20,22,30]$. We also found only one patient $(1.9 \%)$ who developed brain metastases. Due to the low incidence of brain metastases in SCC of the bladder, prophylactic cranial irradiation is not routinely recommended. In cases of metastatic $\mathrm{BC}$, transurethral resection, cystectomy combined with systemic chemotherapy has been proposed apart from partial cystectomy, and radiotherapy [22]. However, there is a paucity of robust data to inform appropriate tailored therapies for different histological subtypes of metastatic BC.

Limitations of our study include the retrospective design and its associated bias, such as selection bias for different treatment schedules. Moreover, due to the inherent limitations of the SEER database, data on specific metastatic sites prior to year 2010 were not available; therefore, the reference period for this study was 2010-2013. We also have no access to data on performance status and chemotherapy which are also important prognostic factors for patients with metastatic BC. So the use of claims based data for this approach will lead to somewhat insufficient estimations. Despite the above limitations, our study fills a gap with respect to histological subtypes and metastatic sites of BC.

In conclusion, based on the SEER database, we compared survival outcomes by histological subtype and site of metastatic lesions in patients with bladder cancer. Our findings suggest that squamous cell carcinoma and presence of multiple metastases portend a poorer prognosis in bladder cancer patients with distant metastasis. Obvious associations are reported with respect to metastatic frequency among patients with squamous and small cell carcinoma. Considering the poor prognosis of metastatic bladder cancer, we should keep an eye on those susceptible organs and sites once the histological subtype is determined.

\section{MATERIALS AND METHODS}

\section{Study design and population}

We identified all patients from 2010-2013 in the Surveillance, Epidemiology, and End Results (SEER) database with BC diagnosed as stage M1, according to the AJCC (American Joint Committee on Cancer) 7th edition. The permission to access the research data was obtained vide reference number 10263-Nov2015. This study was approved by the Clinical investigation ethics committee of the Soochow University (No. 2015103). We used International Classification of Disease for Oncology, Third Edition (ICD-O-3) to determine the histological sub-type. The codes selected were: transitional cell carcinoma $(8120$, 8122,8130 and 8131); adenocarcinoma (8140, 8574, 8260 and 8255); squamous cell carcinoma (8052, 8070, 8071 and 8083); and small cell carcinoma (8041 and 8045).

\section{Outcomes}

Overall survival (OS) was defined as the time period from the first diagnosis of bladder cancer to the date of allcause death, while bladder cancer-specific survival (CSS) was determined until cancer-specific death or censoring, with the end of follow-up occurring on December 31, 2013. 
Table 3: Multivariate analysis of overall survival and bladder cancer-specific survival in patients with metastatic bladder cancer

\begin{tabular}{|c|c|c|c|c|c|c|}
\hline \multirow{2}{*}{ Variables } & \multicolumn{3}{|c|}{ Overall survival } & \multicolumn{3}{|c|}{ Bladder cancer-specific survival } \\
\hline & Hazard Ratio & $95 \% \mathrm{CI}$ & $P$ value & Hazard Ratio & $95 \% \mathrm{CI}$ & $P$ value \\
\hline \multicolumn{7}{|l|}{ Age } \\
\hline$\leq 65$ & 1.000 (reference) & & & & & \\
\hline$>65$ & 1.273 & 1.116 to 1.452 & $<0.001$ & & & \\
\hline \multicolumn{7}{|l|}{ Marital status } \\
\hline Single & 1.000 (reference) & & & 1.000 (reference) & & \\
\hline Married & 0.875 & 0.744 to 1.029 & 0.107 & 0.883 & 0.723 to 1.079 & 0.223 \\
\hline $\begin{array}{l}\text { Divorced/ } \\
\text { Separated }\end{array}$ & 1.027 & 0.836 to 1.262 & 0.799 & 1.044 & 0.806 to 1.352 & 0.744 \\
\hline Widowed & 1.000 & 0.820 to 1.219 & 0.999 & 0.989 & 0.775 to 1.262 & 0.928 \\
\hline \multicolumn{7}{|l|}{ T stage } \\
\hline $\mathrm{T} 0+\mathrm{Tx}$ & 1.000 (reference) & & & & & \\
\hline $\mathrm{T} 1$ & 0.984 & 0.802 to 1.207 & 0.875 & & & \\
\hline $\mathrm{T} 2$ & 1.000 & 0.829 to 1.206 & 1.000 & & & \\
\hline $\mathrm{T} 3$ & 0.944 & 0.731 to 1.218 & 0.657 & & & \\
\hline $\mathrm{T} 4$ & 1.028 & 0.838 to 1.262 & 0.788 & & & \\
\hline \multicolumn{7}{|l|}{ N stage } \\
\hline $\mathrm{N} 0+\mathrm{Nx}$ & 1.000 (reference) & & & & & \\
\hline N1 & 0.877 & 0.712 to 1.080 & 0.215 & & & \\
\hline N2 & 0.942 & 0.800 to 1.109 & 0.475 & & & \\
\hline N3 & 1.148 & 0.857 to 1.537 & 0.355 & & & \\
\hline \multicolumn{7}{|l|}{ Surgery } \\
\hline No & 1.000 (reference) & & & 1.000 (reference) & & \\
\hline Yes & 0.729 & 0.630 to 0.845 & $<0.001$ & 0.975 & 0.817 to 1.165 & 0.781 \\
\hline \multicolumn{7}{|l|}{ Distant metastasis } \\
\hline Single site & 1.000 (reference) & & & 1.000 (reference) & & \\
\hline Multiple sites & 1.428 & 1.260 to 1.618 & $<0.001$ & 1.605 & 1.367 to 1.885 & $<0.001$ \\
\hline \multicolumn{7}{|l|}{ Histology } \\
\hline $\begin{array}{l}\text { Transitional cell } \\
\text { carcinoma }\end{array}$ & 1.000 (reference) & & & 1.000 (reference) & & \\
\hline Adenocarcinoma & 0.593 & 0.427 to 0.825 & 0.002 & 0.599 & 0.389 to 0.922 & 0.020 \\
\hline $\begin{array}{l}\text { Squamous cell } \\
\text { carcinoma }\end{array}$ & 1.496 & 1.121 to 1.995 & 0.006 & 1.733 & 1.225 to 2.452 & 0.002 \\
\hline $\begin{array}{l}\text { Small cell } \\
\text { carcinoma }\end{array}$ & 0.860 & 0.678 to 1.091 & 0.213 & 0.782 & 0.568 to 1.078 & 0.134 \\
\hline
\end{tabular}

\section{Covariates}

Demographic characteristics included age $(<65$ and $>65$ years old), gender (male and female), race (white, black and others), and marital status (single, married, divorced/separated and widowed). Clinical characteristics included pathological $\mathrm{T}$ and $\mathrm{N}$ stages, tumor grade (1-well differentiated, 2-moderately differentiated, 3-poorly differentiated and 4-undifferentiated), surgery, radiotherapy, distant metastasis (single site and multiple sites) as well as tumor histology (TCC, AD, SQCC and SCC).

\section{Statistical analysis}

Categorical variables of Table 1 and metastatic rates of Figure 3 are presented as percentages and analyzed by Chi-squared test and Fisher's exact test. In Figure 1 and 
Figure 2, the Kaplan-Meier method was used to calculate survivor functions and differences in OS, CSS probabilities were estimated using the log rank statistic. The Cox proportional hazards model was used to assess association of variables with survival. Variables showing a significant association with survival on univariate analysis were included in the multivariate model. Statistical analyses were performed using SPSS version 21 (IBM, Chicago, IL, USA); two-sided value of $\mathrm{P}<0.05$ was considered statistically significant. The bar and pie charts were drawn using GraphPad Prism version 6.01 (San Diego, CA).

\section{Abbreviations}

Bladder Cancer (BC), Overall Survival (OS), Bladder cancer-specific survival (CSS), Hazard ratio (HR), Transitional cell carcinoma (TCC), Squamous cell carcinoma (SQCC), Adenocarcinoma (AD), Small cell carcinoma (SCC), Surveillance, Epidemiology, and End Results (SEER), American Joint Committee on Cancer (AJCC), International Classification of Disease for Oncology, Third Edition (ICD-O-3).

\section{ACKNOWLEDGMENTS}

None.

\section{CONFLICTS OF INTEREST}

None declared.

\section{FUNDING}

None.

\section{REFERENCES}

1. Siegel RL, Miller KD, Jemal A. Cancer statistics, 2016. CA Cancer J Clin. 2016; 66:7-30.

2. Parkin DM. The global burden of urinary bladder cancer. Scand J Urol Nephrol. 2008: 12-20.

3. Lopez-Beltran A. Bladder cancer: clinical and pathological profile. Scand J Urol Nephrol. 2008:95-109.

4. Pasquier D, Barney B, Sundar S, Poortmans P, Villa S, Nasrallah H, Boujelbene N, Ghadjar P, Lassen-Ramshad Y, Senkus E, Oar A, Roelandts M, Amichetti M, et al. Small Cell Carcinoma of the Urinary Bladder: A Retrospective, Multicenter Rare Cancer Network Study of 107 Patients. Int J Radiat Oncol Biol Phys. 2015; 92:904-10.

5. Koay EJ, Teh BS, Paulino AC, Butler EB. A Surveillance, Epidemiology, and End Results analysis of small cell carcinoma of the bladder: epidemiology, prognostic variables, and treatment trends. Cancer. 2011; 117:5325-33.
6. Rogers CG, Palapattu GS, Shariat SF, Karakiewicz PI, Bastian PJ, Lotan Y, Gupta A, Vazina A, Gilad A, Sagalowsky AI, Lerner SP, Schoenberg MP. Clinical outcomes following radical cystectomy for primary nontransitional cell carcinoma of the bladder compared to transitional cell carcinoma of the bladder. J Urol. 2006; 175:2048-53.

7. Scosyrev E, Yao J, Messing E. Urothelial carcinoma versus squamous cell carcinoma of bladder: is survival different with stage adjustment. Urology. 2009; 73:822-7.

8. Abdollah F, Sun M, Jeldres C, Schmitges J, Thuret R, Djahangirian O, Tian Z, Shariat SF, Perrotte P, Montorsi F, Karakiewicz PI. Survival after radical cystectomy of nonbilharzial squamous cell carcinoma vs urothelial carcinoma: a competing-risks analysis. BJU Int. 2012; 109:564-9.

9. Izard JP, Siemens DR, Mackillop WJ, Wei X, Leveridge MJ, Berman DM, Peng Y, Booth CM. Outcomes of squamous histology in bladder cancer: a population-based study. Urol Oncol. 2015; 33:425.e7-13.

10. Coleman RE. Metastatic bone disease: clinical features, pathophysiology and treatment strategies. Cancer Treat Rev. 2001; 27:165-76.

11. Loehrer PJ, Einhorn LH, Elson PJ, Crawford ED, Kuebler P, Tannock I, Raghavan D, Stuart-Harris R, Sarosdy MF, Lowe BA. A randomized comparison of cisplatin alone or in combination with methotrexate, vinblastine, and doxorubicin in patients with metastatic urothelial carcinoma: a cooperative group study. J Clin Oncol. 1992; 10:1066-73.

12. der Maase H v, Sengelov L, Roberts JT, Ricci S, Dogliotti L, Oliver T, Moore MJ, Zimmermann A, Arning M. Longterm survival results of a randomized trial comparing gemcitabine plus cisplatin, with methotrexate, vinblastine, doxorubicin, plus cisplatin in patients with bladder cancer. J Clin Oncol. 2005; 23:4602-8.

13. Bajorin DF, Dodd PM, Mazumdar M, Fazzari M, McCaffrey JA, Scher HI, Herr H, Higgins G, Boyle MG. Long-term survival in metastatic transitional-cell carcinoma and prognostic factors predicting outcome of therapy. J Clin Oncol. 1999; 17: 3173-81.

14. Bellmunt J, Albanell J, Paz-Ares L, Climent MA, González-Larriba JL, Carles J, de la Cruz JJ, Guillem V, Díaz-Rubio E, Cortés-Funes H, Baselga J. Pretreatment prognostic factors for survival in patients with advanced urothelial tumors treated in a phase I/II trial with paclitaxel, cisplatin, and gemcitabine. Cancer. 2002; 95:751-7.

15. Lin CC, Hsu CH, Huang CY, Tsai YC, Huang $\mathrm{KH}$, Cheng $\mathrm{AL}, \mathrm{Pu} \mathrm{YS}$. Prognostic factors for metastatic urothelial carcinoma treated with cisplatin and 5-fluorouracilbased regimens. Urology. 2007; 69:479-84.

16. Stadler WM, Hayden A, von der Maase H, Roychowdhury D, Dogliotti L, Seymour L, Kaufmann D, Moore M. Longterm survival in phase II trials of gemcitabine plus cisplatin for advanced transitional cell cancer. Urol Oncol. 2002; $7: 153-7$. 
17. Bellmunt J, Choueiri TK, Fougeray R, Schutz FA, Salhi Y, Winquist E, Culine S, der Maase H v, Vaughn DJ, Rosenberg JE. Prognostic factors in patients with advanced transitional cell carcinoma of the urothelial tract experiencing treatment failure with platinum-containing regimens. J Clin Oncol. 2010; 28: 1850-5.

18. Zaghloul MS, Nouh A, Nazmy M, Ramzy S, Zaghloul AS, Sedira MA, Khalil E. Long-term results of primary adenocarcinoma of the urinary bladder: a report on 192 patients. Urol Oncol. 2006; 24: 13-20.

19. Wright JL, Porter MP, Li CI, Lange PH, Lin DW. Differences in survival among patients with urachal and nonurachal adenocarcinomas of the bladder. Cancer. 2006; 107:721-8.

20. Mukesh M, Cook N, Hollingdale AE, Ainsworth NL, Russell SG. Small cell carcinoma of the urinary bladder: a 15-year retrospective review of treatment and survival in the Anglian Cancer Network. BJU Int. 2009; 103:747-52.

21. Patel SG, Stimson CJ, Zaid HB, Resnick MJ, Cookson MS, Barocas DA, Chang SS. Locoregional small cell carcinoma of the bladder: clinical characteristics and treatment patterns. J Urol. 2014; 191:329-34.

22. Bex A, Sonke GS, Pos FJ, Brandsma D, Kerst JM, Horenblas S. Symptomatic brain metastases from small-cell carcinoma of the urinary bladder: The Netherlands Cancer Institute experience and literature review. Ann Oncol. 2010; 21:2240-5.

23. Dores GM, Qubaiah O, Mody A, Ghabach B, Devesa SS. A population-based study of incidence and patient survival of small cell carcinoma in the United States, 1992-2010. BMC Cancer. 2015; 15:185.

24. Koay EJ, Teh BS, Paulino AC, Butler EB. Treatment trends and outcomes of small-cell carcinoma of the bladder. Int J Radiat Oncol Biol Phys. 2012; 83:64-70.
25. Xylinas E, Rink M, Robinson BD, Lotan Y, Babjuk M, Brisuda A, Green DA, Kluth LA, Pycha A, Fradet Y, Faison T, Lee RK, Karakiewicz PI, et al. Impact of histological variants on oncological outcomes of patients with urothelial carcinoma of the bladder treated with radical cystectomy. Eur J Cancer. 2013; 49:1889-97.

26. Lughezzani G, Sun M, Jeldres C, Alasker A, Budäus L, Shariat SF, Latour M, Widmer H, Duclos A, JolivetTremblay M, Montorsi F, Perrotte P, Karakiewicz PI. Adenocarcinoma versus urothelial carcinoma of the urinary bladder: comparison between pathologic stage at radical cystectomy and cancer-specific mortality. Urology. 2010; 75:376-81.

27. Geynisman DM, Handorf E, Wong YN, Doyle J, Plimack ER, Horwitz EM, Canter DJ, Uzzo RG, Kutikov A, Smaldone MC. Advanced small cell carcinoma of the bladder: clinical characteristics, treatment patterns and outcomes in 960 patients and comparison with urothelial carcinoma. Cancer Med. 2016; 5: 192-9.

28. Abrahams NA, Moran C, Reyes AO, Siefker-Radtke A, Ayala AG. Small cell carcinoma of the bladder: a contemporary clinicopathological study of 51 cases. Histopathology. 2005; 46:57-63.

29. Choong NW, Quevedo JF, Kaur JS. Small cell carcinoma of the urinary bladder. The Mayo Clinic experience. Cancer. 2005; 103:1172-8.

30. Siefker-Radtke AO, Dinney CP, Abrahams NA, Moran C, Shen Y, Pisters LL, Grossman HB, Swanson DA, Millikan RE. Evidence supporting preoperative chemotherapy for small cell carcinoma of the bladder: a retrospective review of the M. D. Anderson cancer experience. J Urol. 2004; 172:481-4. 